\title{
Regional CMS Modeling; Southwest Florida Gulf Coast
}

US Army Corps of Engineers ${ }_{\circledast}$

by Kelly R. Legault and Tanya M. Beck

PURPOSE: This Coastal and Hydraulics Engineering technical note (CHETN) describes a regional application of the U.S. Army Corps of Engineers (USACE) Engineer Research and Development Center (ERDC) Coastal Modeling System (CMS). This application spans three counties and over 70 miles of southwest Florida shoreline along the Gulf of Mexico. The study region is entirely within the USACE Jacksonville District (SAJ) jurisdiction and includes the coastline from Clearwater Beach in Pinellas County, FL, to Venice Beach in Sarasota County, FL (Figure 1). Active federal projects include the Pinellas County Shore Protection Project (SPP), Tampa Harbor Deeping Project, Manatee County SPP at Anna Maria Island, the City of Sarasota SPP at Lido Key, Sarasota County SPP at Venice Beach, and a number of federally authorized channels. Local projects exist as well in Longboat Key and at Siesta Key. This effort was supported by SAJ and ERDC through the USACE Regional Sediment Management (RSM) Program.

INTRODUCTION: Sediment resource investigations off the Gulf Coast of Florida have demonstrated that sediment is indeed becoming more and more scarce. It is questionable whether an adequate volume of beach quality sediment (sand) offshore exists that can be delivered to the beach in a manner that is economically feasible. Often sediment sources that are suitable are far removed from the project site, and alternative sources must be found for a project to be economically viable. Aerial photography, hydrographic surveys, and lidar data have shown a clear pattern of high value beach sand moving into inlet channels/shoals (Legault, in preparation). Mining this resource of beach quality sediment carries inherent risks of disrupting the delicate balance between environmental forcing conditions and the morphology of an inletebb shoal complex. Substantial removal of sediment from an inlet complex may alter the ebb shoal morphology or local/regional sediment transport patterns in such a way that there would be adverse effects on adjacent beaches.

For Federal projects where it is deemed necessary to mine sediment from an ebb shoal, the CMS (a process-based, morphology-change model) can be used to determine the response and evolution of inlet and ebb shoal morphology as a function of mining of the ebb shoal for sediments. Additionally, the CMS can be used to map the wave climate in the vicinity of the inlet-ebb shoal complex and to visualize sediment transport pathways that link the ebb shoal to adjacent beaches. This CHETN describes the use of a regional CMS model that spans the 70-mile study region. Nested grids are used in this investigation to calculate morphologic change at the inlets of the southwest Gulf Coast of Florida. 


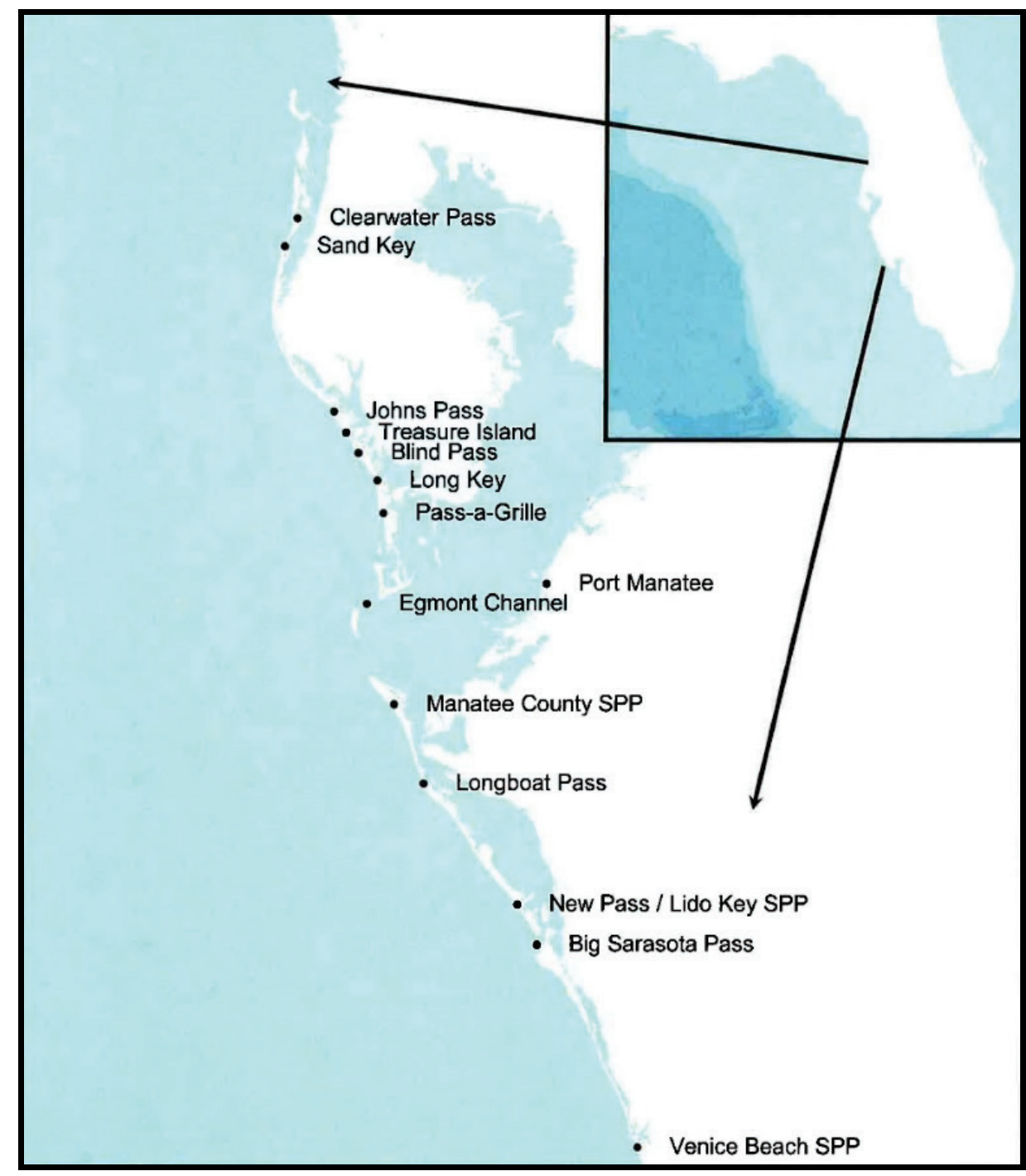

Figure 1. Sediment budget extent and active USACE Jacksonville District (SAJ) projects in Pinellas, Manatee, and Sarasota Counties, FL.

METHOD: The CMS is a product of the Coastal Inlets Research Program (http://cirp.usace. army.mil), a USACE Navigation Research Development and Technology Program administered by Headquarters, USACE. The CMS is a numerical model specifically designed for desk-top applications and is capable of simulating relevant hydrodynamic and sediment transport processes at tidal inlets. The CMS is composed of two coupled models: (1) CMS-Flow (Buttolph et al. 2006; Wu et al. 2010; Sanchez et al. 2011a; Sanchez et al. 2011b), and (2) CMS-Wave (Lin et al. 2008; Lin et al. 2011). CMS-Flow is a finite-volume, depth-averaged model that can calculate water surface elevation, current, sediment transport (Camenen and Larson 2007), and morphology change.

Within CMS, CMS-Flow is coupled with CMS-Wave which calculates spectral wave propagation with wave refraction, diffraction, reflection, shoaling, and breaking. CMS-Wave also provides wave information for sediment transport calculations. Typically, the CMS is forced at the offshore boundary using water surface elevation and wave data. Wave data can be obtained 
from a variety of sources such as National Oceanic and Atmospheric Administration (NOAA) buoys, the WaveWatch III model, and wave hindcasts by ERDC Wave Information Study (WIS). Water level data may either be measured or may be calculated from a regional model such as ERDC Advanced CIRCulation (ADCIRC) (Militello and Zundel 2002). For the application detailed in this CHETN, the CMS model was constructed on a regional scale and forced with measured water level data at the northern and southern lateral boundaries.

A South-West Florida (SWFL) Regional CMS Model grid was developed representing the southwest Florida coast for the purpose of extracting water levels for nested local inlet-scale CMS grids (Figure 2). The cross-shore distance of the SWFL Regional CMS Model grid is approximately 24.9 miles from the throat of Big Sarasota Pass and extends approximately 53.4 miles in the alongshore from Treasure Island to South Venice Inlet, including all of Tampa Bay. The SWFL Regional CMS Model was driven along the ocean boundary with 6-minute (min) measured water levels from NOAA Stations 8726724 Clearwater Beach, FL, and 8725110 Naples, FL. The finest resolution of the model grid cells was set to 12.5 meters (m) (41.5 feet [ft]) in the inlet throat, and $25 \mathrm{~m}(82 \mathrm{ft})$ in the main bay channels, ebb-tidal delta, and nearshore. Maximum cells sizes in the bay reach $120 \mathrm{~m}$ (393 ft) over large open bay expanses and expand to $800 \mathrm{~m}(2,624 \mathrm{ft})$ along the offshore boundary. The CMS-Flow Regional Model grid has 132,265 cells with which only water surface elevation and current are calculated. Wave heights can also be calculated with nested grids by CMS-Wave.

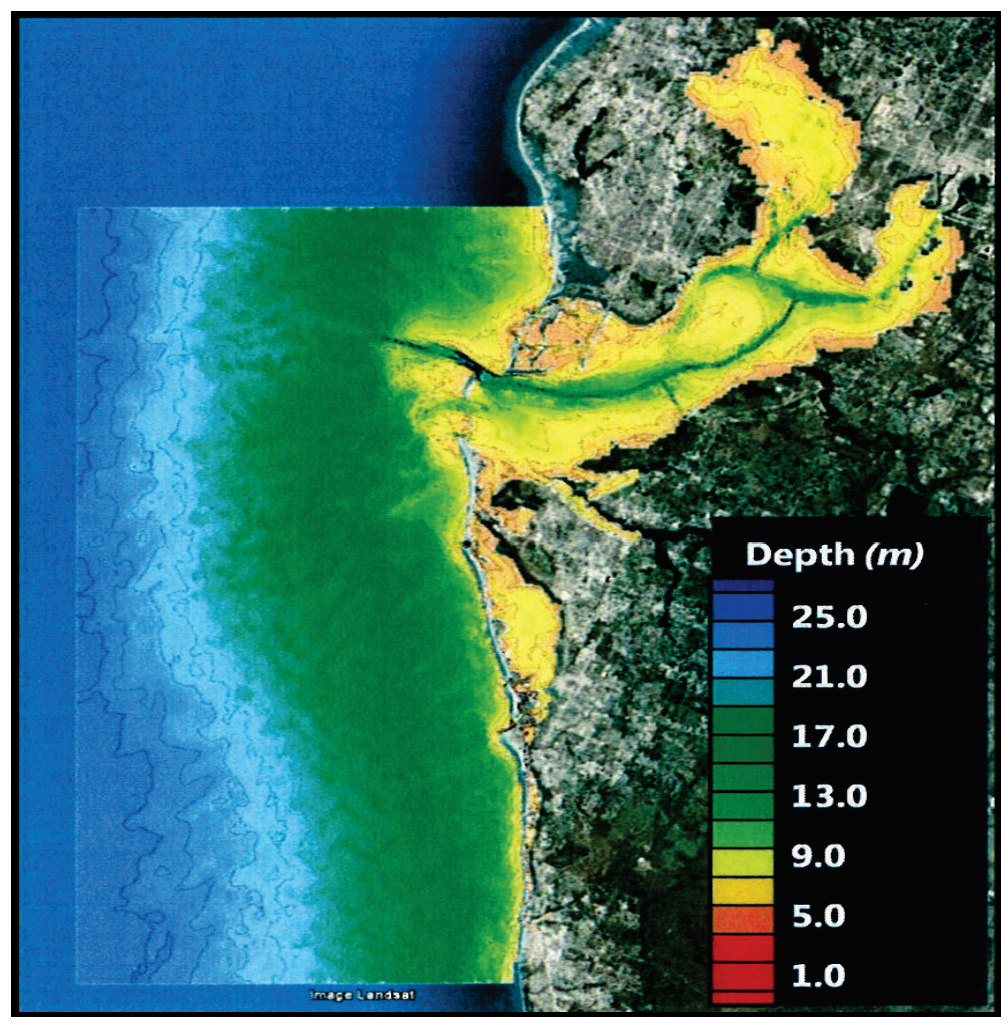

Figure 2. South-West Florida (SWFL) Regional CMS Model grid bathymetry. 
Nested grids have been developed for SAJ project regions (Figure 3), which include Passage Key Inlet (Manatee County SPP), New Pass and Big Sarasota Pass (Lido Key SPP), Venice Inlet (Sarasota County SPP), and Longboat Key (in development for Longboat Key Feasibility Study). Grids for Johns Pass and Blind Pass have also been developed and continue to be refined by ERDC and University of South Florida (USF). Information gleaned from the CMS nested grids are presently being used to develop inlet management plans for the State of Florida.

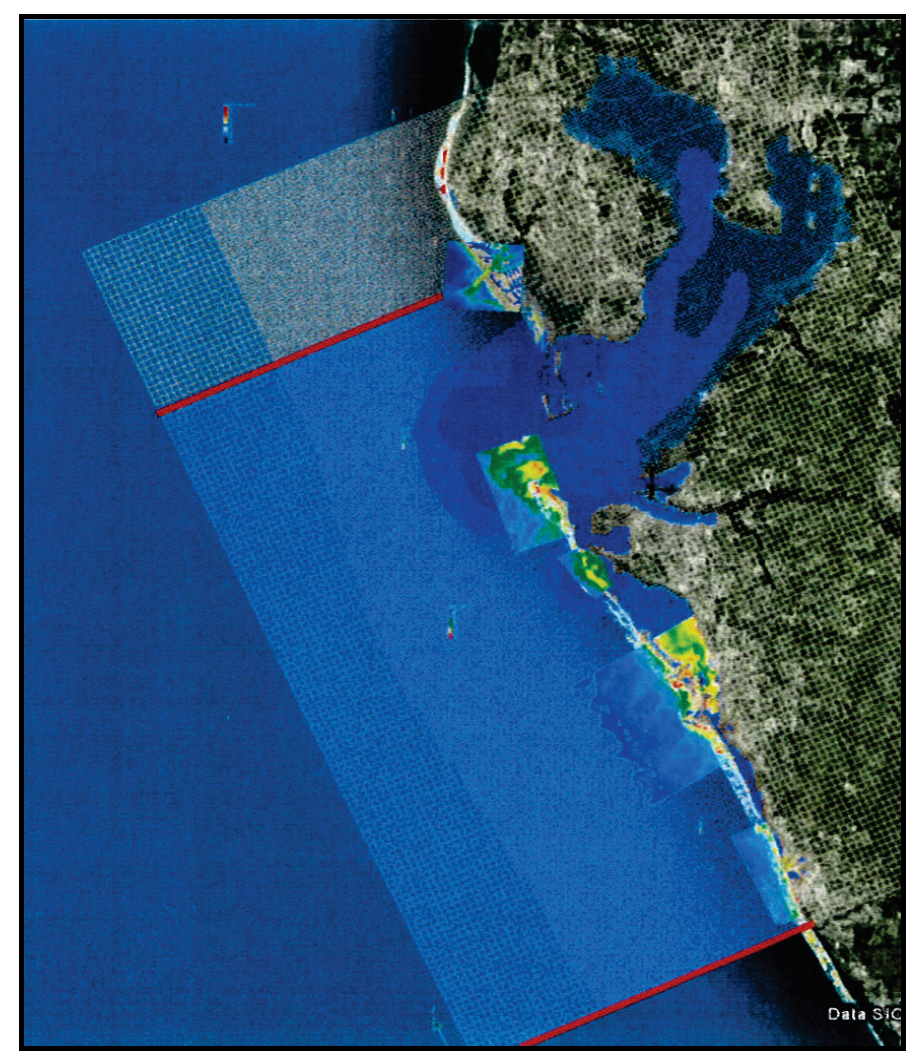

Figure 3. South-West Florida (SWFL) Regional CMS Model grid and nested subgrids for Johns Pass, Blind Pass, Passage Key Inlet, Longboat Pass, New Pass, Big Sarasota Pass, and Venice Inlet, FL.

Nested grid examples: New Pass and Big Sarasota Pass. To support the Lido Key SPP, the CMS was set up to calculate waves, hydrodynamics, sediment transport, and morphology change for New Pass and Big Sarasota Pass (Figure 4). Both flow and wave calculations are nested. The CMS-Flow grid extends approximately 7.5 miles offshore from the throat of Big Sarasota Pass and approximately 6.2 miles both north and south of the inlet. The CMS-Wave grid has the same alongshore and offshore extent as the CMS-Flow grid. The offshore boundary was set to be at the location of the WaveWatch III output location.

Nested grid examples: Passage Key Inlet and Venice Inlet. Nested grids were also developed to support Manatee County SPP and Sarasota County SPP (Figures 5 and 6). Grids for Johns Pass and Blind Pass have been developed (Wang and Beck 2012) and are being refined by USF in support of the State of Florida inlet management plans. 


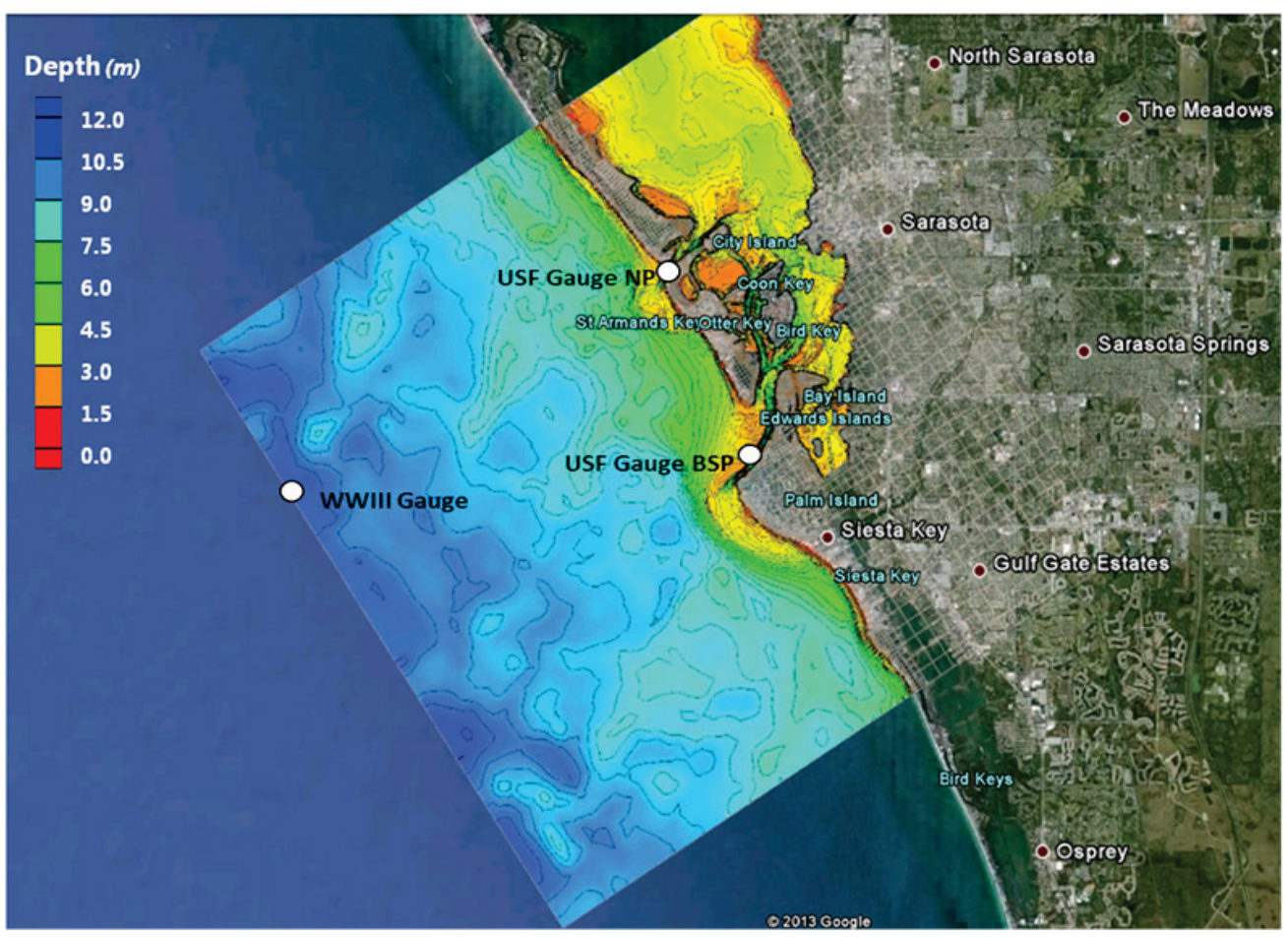

Figure 4. New Pass and Big Sarasota Pass CMS grid bathymetry, WaveWatch III (WWIII) data location, and University of South Florida (USF) hydrodynamic and water level gages in New Pass (NP) and in Big Sarasota Pass (BSP).

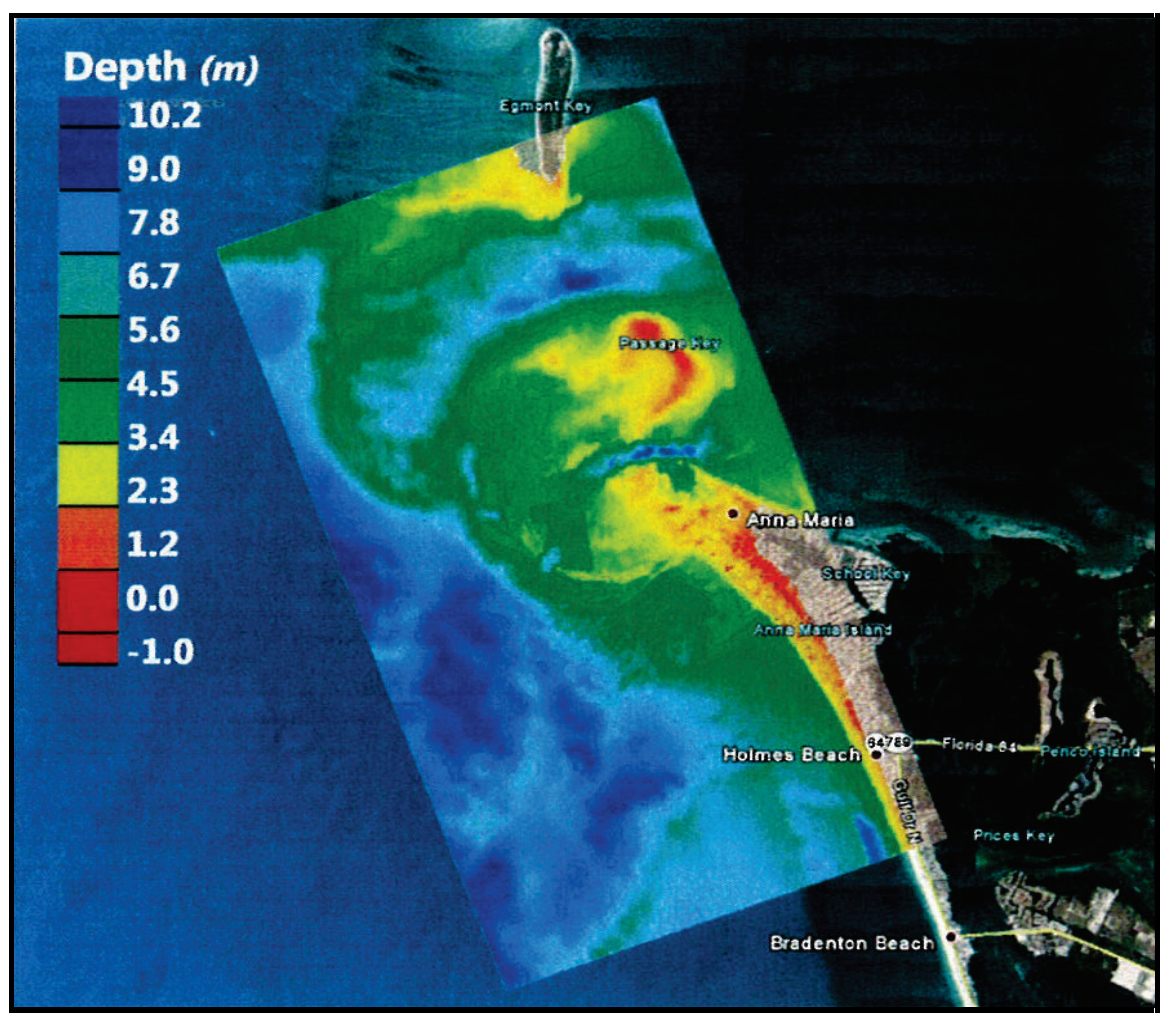

Figure 5. Passage Key Inlet CMS grid. 


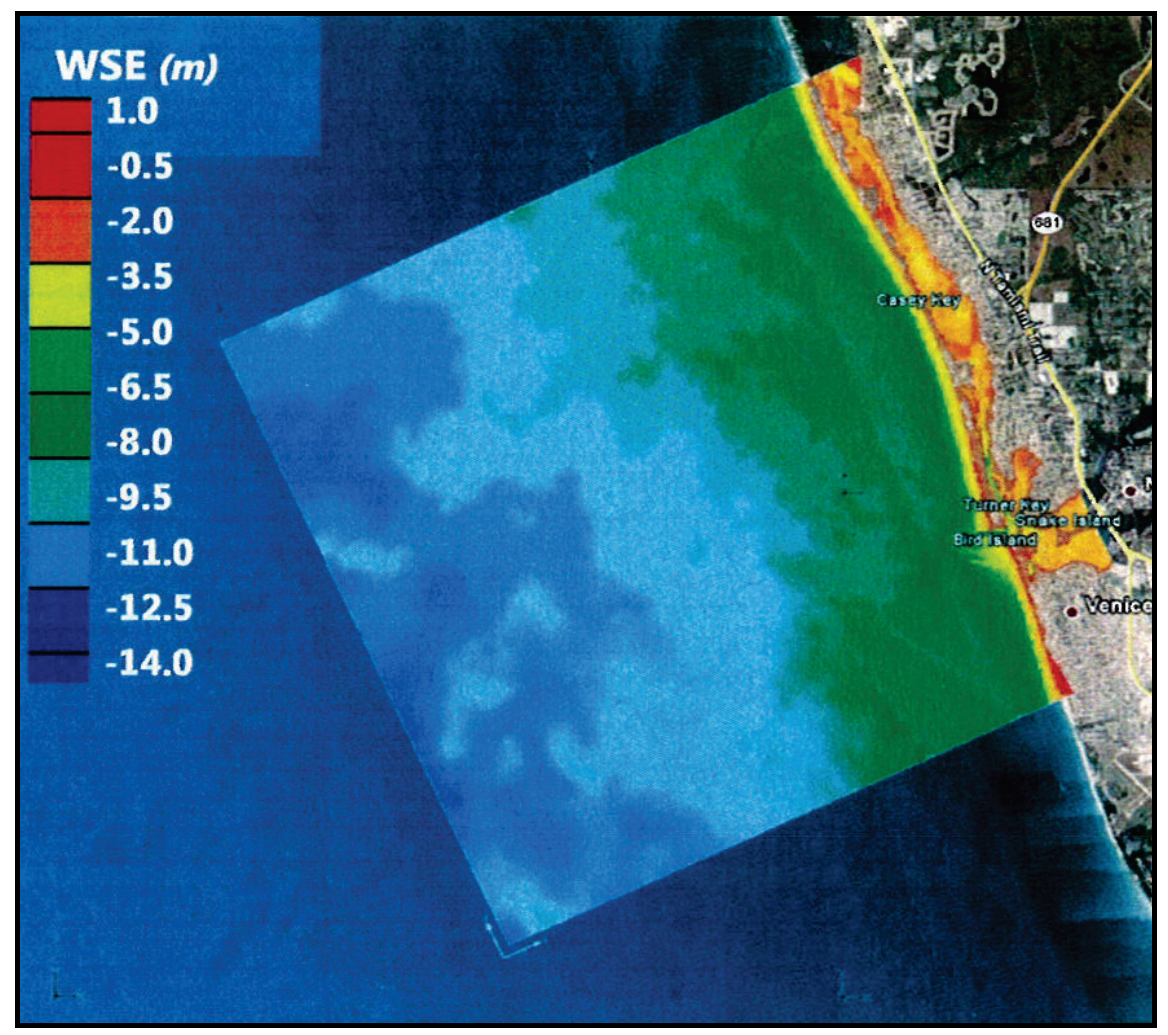

Figure 6. Venice Inlet CMS grid.

\section{RESULTS:}

SWFL regional CMS model. The model simulation period was from 24 February to 31 March 2006. A ramping period, or spin-up period, of 6 hours (hr) was set, which is typical for an implicit model. The hydrodynamic time-step was set to 600 seconds (sec) to ensure capturing the tidal signal. The SWFL Regional CMS Model was calibrated to water levels measured in New Pass and Big Sarasota Pass by USF. The correlation coefficients $\left(\mathrm{R}^{2}\right)$ for measured and calculated water levels are 0.86 for Big Sarasota Pass and 0.85 for New Pass.

Nested model examples: New Pass and Big Sarasota Pass. The calculated water levels for the calibration time period were compared with the measurements by USF (Wang et al. 2007) in Big Sarasota Pass and New Pass. For the two bay gauges, the correlation coefficients $\left(\mathrm{R}^{2}\right)$ between the measured and calculated water surface elevations are 0.90 for Big Sarasota Pass, and 0.90 for New Pass. Comparisons of the measured depth-averaged currents also show a good agreement with the calculated results. The correlation coefficients $\left(\mathrm{R}^{2}\right)$ between the measured and calculated along-channel current speeds are 0.87 for Big Sarasota Pass and 0.84 for New Pass. Morphology change, illustrated in Figure 7 where warm colors represent accretion (deposition) and cool colors represent erosion, captures the overall morphologic change of the shoal features including the channel infilling, ebb shoal platform deflation, and migration of sediments to the attachment point of down-drift beaches. 


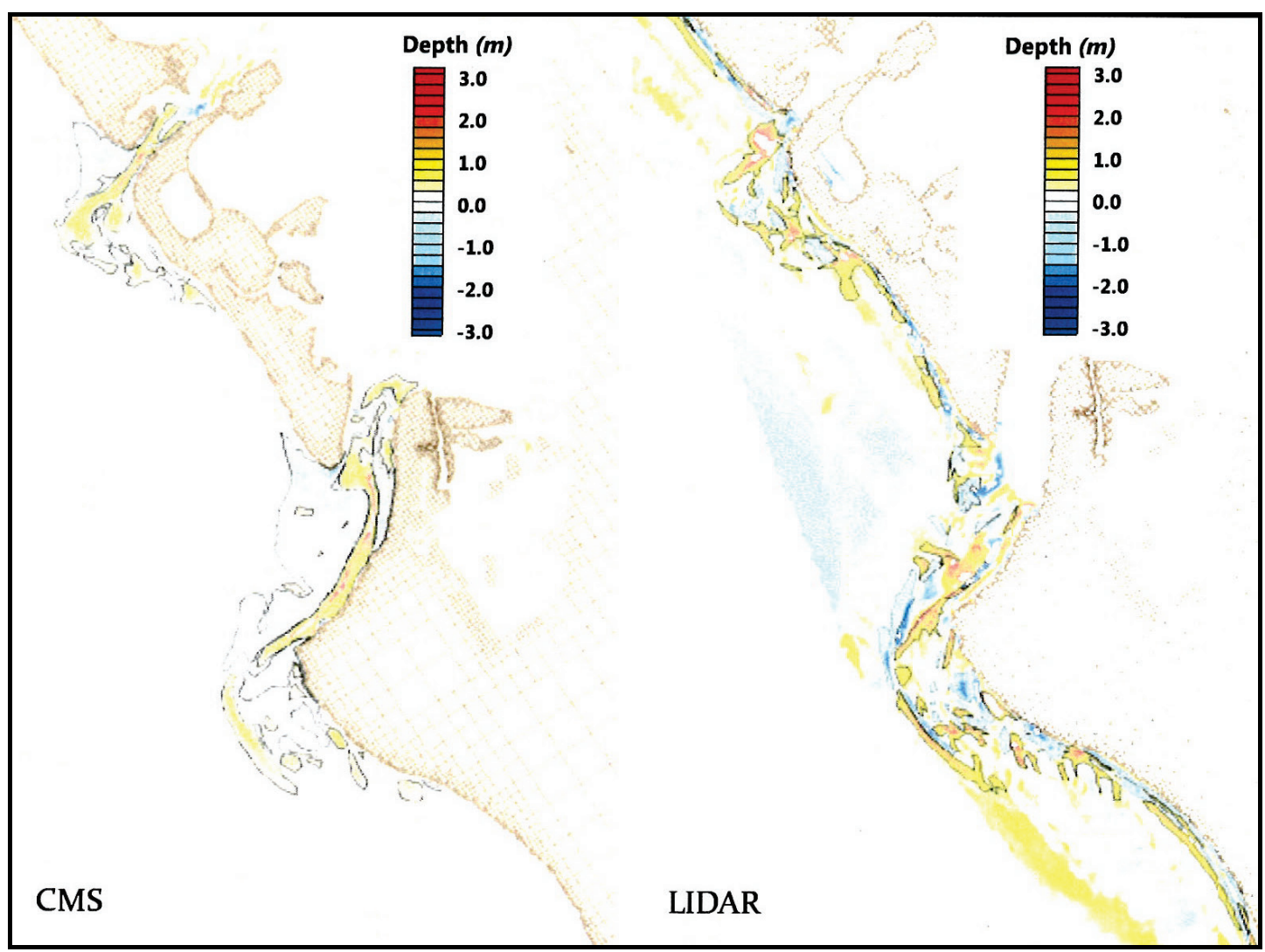

Figure 7. Modeled (left) and measured (right) morphologic change at Big Sarasota Pass and New Pass, FL, 2004.

DISCUSSION: The arrangement of the SWFL Regional CMS Model grid and associated nested subgrids allows for the analysis of multiple inlets under identical environmental forcing conditions. It also allows for the continuous development, refinement, and validation of nested models. Furthermore, it provides a means of developing water level boundary conditions using NOAA measured water levels for subgrids for any time period for which the NOAA National Ocean Survey (NOS) has measurements at Clearwater and Venice, FL. This is an advantage of the nested model.

The SWFL Regional CMS Model grid and associated subgrids puts into place the first regional CMS modeling framework that has been used to determine the morphologic change in multiple barrier-inlet systems along the Gulf Coast of southwest Florida. For this region, mining of the ebb shoal and navigation channels for navigation and storm damage reduction projects can have significant regional implications for beach change, estuarine hydrodynamics, and long-term stability of tidal inlets. The significant volumetric change resulting from these short-term projects can be much greater than expected nonproject equilibration rates, given the natural processes for this region. Modeling multiple nested grids along concurrent timeframes provides a means to predict updrift and downdrift effects on the hydrodynamics and morphodynamics of the region where USACE dredging and placement projects are conducted.

The regional model and local grids at New Pass and Big Sarasota Pass have been used to develop engineering alternatives to determine the best practices for mining the ebb shoal while avoiding 
adverse effects to adjacent shorelines and beaches. At Passage Key inlet, the regional and local CMS model was used to develop the borrow site area for emergency beach nourishment following the passage of Hurricane Debby. The model at Venice Inlet will be used to determine if modification to the existing jetty at the inlet will improve sediment bypassing and mitigate the erosion hotspot downdrift of the structure. Most importantly, the subgrids for the southwest Florida coast will be used to develop inlet management plans for the State of Florida. This regional and local scale study, supported by the USACE RSM Program, is both appropriate and necessary for the development of the inlet management plans.

CONCLUSIONS: This CHETN documents the development and use of a regional CMS model and nested models for the passes in southwest Florida along the Gulf of Mexico. At present, the SWFL Regional CMS Model grid and subgrids are being used to develop engineering solutions at the project scale and to develop inlet management plans for the State of Florida.

ADDITIONAL INFORMATION: This CHETN was prepared by Kelly R. Legault, U.S. Army Engineer District, SAJ, and Tanya M. Beck, ERDC. Funding for this study was provided by the USACE RSM Program, a Navigation, Research, Development, and Technology program administered by Headquarters, USACE. Additional information pertaining to the RSM Program can be found at the RSM website http://rsm.usace.army.mil.

Questions regarding this CHETN may be addressed to Kelly R. Legault (Kelly.R.Legault@, usace.army.mil), SAJ, Senior Coastal Engineer, Engineering Division or Tanya M. Beck (Tanya.M.Beck@usace.army.mil), Chief, Coastal Engineering Branch, Navigation Division, Coastal and Hydraulics Laboratory, ERDC. Additional information pertaining to the RSM program can be obtained from the USACE RSM Program Manager, Linda S. Lillycrop (Linda.S.Lillycrop@usace.army.mil).

This ERDC CHETN should be cited as:

Legault, K. R., and T.M. Beck. 2016. Regional CMS modeling; Southwest Florida Gulf Coast. ERDC/CHETN-XIV-42. Vicksburg, MS: U.S. Army Engineer Research and Development Center.

\section{REFERENCES}

Buttolph, A. M., C. W. Reed, N. C. Kraus, N. Ono, M. Larson, B. Camenen, H. Hanson, T. Wamsley, and A. K. Zundel. 2006. Two-dimensional depth-averaged circulation model CMS-M2D: Version 3.0; Report 2, Sediment transport and morphology change. ERDC/CHL TR-06-7. Vicksburg, MS: U.S. Army Engineer Research and Development Center. http://acwc.sdp.sirsi.net/client/search/asset/1000764

Camenen, B., and M. Larson. 2007. A unified sediment transport formulation for coastal inlet application. ERDC/CHL CR-07-1. Vicksburg, MS: U.S. Army Engineer Research and Development Center. http://acwc.sdp.sirsi.net/client/search/asset/1000072

Lin, L., Z. Demirbilek, H. Mase, J. Zheng, and F. Yamada. 2008. CMS-Wave: A nearshore spectral wave processes model for coastal inlets and navigation projects. ERDC/CHL TR-08-13. Vicksburg, MS: U.S. Army Engineer Research and Development Center. http://acwc.sdp.sirsi.net/client/search/asset/1000803

Lin, L., Z. Demirbilek, R. Thomas, and J. Rosati, III. 2011. Verification and validation of the Coastal Modeling System; Report 2; CMS-Wave. ERDC/CHL TR-11-10. Vicksburg, MS: U.S. Army Engineer Research and Development Center. http://acwc.sdp.sirsi.net/client/en US/search/asset/1005705 
Legault, K. R. (In preparation). Pinellas, Manatee, and Sarasota Counties; Regional sediment budget. ERDC/CHL Technical Note. Vicksburg, MS: U.S. Army Engineer Research and Development Center.

Militello, A., and A. K. Zundel. Coupling of regional and local circulation models ADCIRC and M2D. ERDC/CHL CHETN-IV-42. Vicksburg, MS: U.S. Army Engineer Research and Development Center. http://acwc.sdp.sirsi.net/client/search/asset/1000401

Sanchez, A., W. Weiming, T. M. Beck, H. Li, J. Rosati, III, R. Thomas, J. D. Rosati, Z. Demirbilek, M. Brown, and C. Reed. 2011a. Verification and validation of the Coastal Modeling System: Report 3; CMS-Flow, hydrodynamics. ERDC/CHL TR-11-10. Vicksburg, MS: U.S. Army Engineer Research and Development Center. http://acwc.sdp.sirsi.net/client/search/asset/1005706

Sanchez, A., W. Weiming, T. M. Beck, H. Li, J. D. Rosati, Z. Demirbilek, and M. Brown. 2011b. Verification and validation of the Coastal Modeling System: Report 4; CMS-Flow, Sediment transport and morphology change. ERDC/CHL TR-11-10. Vicksburg, MS: U.S. Army Engineer Research and Development Center. http://acwc.sdp.sirsi.net/client/search/asset/1005707

Wang, P., D. K. Tidwell, T. M. Beck, and N. C. Kraus. 2007. Sedimentation patterns in a stabilized migratory inlet, Blind Pass, Florida. Tampa, FL: University of South Florida, Department of Geology Faculty Publications.

Wang, P., and T. M. Beck. 2012. Morphodynamics of an anthropogenically altered dual-inlet system: John's Pass and Blind Pass, west-central Florida, USA. In Marine Geology, Vol. 291-294, 162-175. Amsterdam, The Netherlands: Elsevier Publishing Company.

Wu, W., M. Zhang, and A. Sanchez. 2010. An implicit 2-D shallow water flow model on unstructured quadtree rectangular mesh. Journal of Coastal Research: Special Issue 59:15-26.

NOTE: The contents of this technical note are not to be used for advertising, publication,

or promotional purposes. Citation of trade names does not constitute an official endorsement or approval of the use of such products. 